Bull. Chem. Soc. Ethiop. 2016, 30(3), 473-484.

Printed in Ethiopia

ISSN 1011-3924

DOI: http://dx.doi.org/10.4314/bcse.v30i3.16

(c) 2016 Chemical Society of Ethiopia

\title{
ADSORPTION OF Pb(II) IONS FROM AQUEOUS SOLUTION USING LIGNIN FROM HAGENIA ABYSSINICA
}

\author{
Belete Tesfaw, Fekadu Chekol, Solomon Mehretie and Shimelis Admassie*
}

Department of Chemistry, Addis Ababa University, PO Box 1176, Addis Ababa, Ethiopia

(Received January 4, 2016; revised August 25, 2016)

\begin{abstract}
The adsorption of lead(II) ions from aqueous solution onto alkali lignin extracted from Hagenia abyssinica was investigated by electrochemical methods. The effect of solution $\mathrm{pH}$, lignin dosage and contact time were investigated at room temperature in a batch system. Adsorption equilibrium was approached within 80 min. The adsorption kinetics data were described by pseudo-second-order kinetics model, while the equilibrium data were well fitted using the Freundlich model. A maximum adsorption capacity was found to be $80.41 \mathrm{mg} \mathrm{g}^{-1}$ of the dry weight of lignin.
\end{abstract}

KEY WORDS: Lignin, Adsorption Capacity, Lead(II) ion, Square wave anodic stripping voltammetry

\section{INTRODUCTION}

Environmental pollution or introduction of undesirable substances from different sources to the environment is a serious challenge facing mankind in our century. Sources for environmental pollution can be natural processes like volcanoes or anthropogenic like industrial wastewater and the release of toxic compounds. Excessive levels of heavy metals in water are an environmental hazard because of their toxicity, accumulation in the food chain and persistence in nature [1-3]. Water contamination by heavy metals such as $\mathrm{Cr}, \mathrm{Cd}, \mathrm{Hg}, \mathrm{Cu}, \mathrm{Ni}, \mathrm{As}$ and $\mathrm{Pb}$, is a big environmental concern and it requires significant attention [4-8]. The major sources of heavy metal pollution are municipal waste, metal plating facilities, mining operations, fertilizer industries, tanneries, batteries and paper industries [9-12]. Heavy metals are non-biodegradable and they can be accumulated by tissues of living organisms [13]. If the metals are ingested beyond the permitted limit, they can cause serious diseases and disorders [13, 14]. Therefore, it is necessary to treat metal contaminated wastewater prior to its discharge into the environment.

There are different techniques for heavy metal removal from aqueous effluents such as chemical precipitation [15], coagulation-flocculation [16], adsorption [17], ion exchange [18], oxidation [19], membrane filtration technologies [20], biological treatment [21, 22], electrochemical deposition [23] and chemical immobilization technique [24]. Among the various wastewater treatment techniques described, adsorption has become one of the alternative treatments because of its flexibility and simplicity of design, high efficiency, availability of different low cost adsorbents and ease of operation [25].

A lot of research works have been conducted on different types of adsorbents, such as those of mineral, organic or biological origin, magnetic nanoparticles [26, 27], nanosheet-structured materials [28], zeolites [29], industrial by-products [30], agricultural wastes [31, 31], biomass [33] and lignin and lignocellulose materials [8, 34, 35]. However, wastewater treatment technologies are still requiring new environmentally friendly, scalable, cheap and effective materials. The present study focuses on the removal of lead which is one of the most toxic heavy metals and is harmful to human beings and other creatures [36-40] using alkali lignin extracted from Hagenia abyssinica.

*Corresponding author. E-mail: shimelis.admassie@aau.edu.et; shimadm09@gmail.com 
Lignin is one of the major constituent of wood and non-wood plants after cellulose and hemicellulose. It is a material that is available in large quantities in many parts of the world. As a three dimensional polymer, lignin is a polyphenolic, cell wall constituents [41] found exclusively in the plants kingdom. It is biosynthesized through enzyme-catalyzed dehydrogenative polymerization of three basic precursors: coniferyl, sinapyl and p-coumaryl alcohols. Each of the precursors is connected by series of ether and carbon-carbon linkage with other precursors to form the lignin polymer. Lignin contains various functional groups such as methoxyl, phenolic, aromatic carboxyl, alcohol and aldehyde, which increase its potential to adsorb heavy metals from aqueous solution $[42,43]$.

Alkali lignin can provide an environmentally safe and sustainable source of material for heavy metal removal. Despite its efficiency and eco-friendly character, to our knowledge, lignin from Hagenia abyssinica has not been previously investigated for heavy metal adsorption. In this paper we report the adsorption behaviors, kinetics and mechanisms of the alkali lignin for removal of $\mathrm{Pb}$ (II) ion from aqueous solution. In addition, the effects of different parameters such as deposition potential, deposition time, adsorbent dose and contact time were optimized.

\section{EXPERIMENTAL}

\section{Apparatus}

Square wave anodic stripping voltammetry (SWASV) measurements were performed using $\mathrm{CH}$ Instruments Electrochemical Analyzer (CHI840C). A three-electrode configuration consisting of bismuth film modified glassy carbon working electrode, $\mathrm{Ag} / \mathrm{AgCl} / \mathrm{KCl}$ (saturated) reference electrode, and a platinum wire as counter electrode was employed. All electrochemical experiments were carried out in one-compartment voltammetric cells $(20 \mathrm{~mL})$ at ambient temperature. Magnetic stirrer together with magnetic bar was used, when needed. FTIR spectroscopy and elemental analysis were carried out using Perkin Elmer Spectrum 65 FT-IR Spectrometer and Perkin-Elmer 240Q Elemental analyzer. Gallenkamp flask shaker was used for batch adsorption experiments. All pH measurement was carried out using a JENWAY 3510 $\mathrm{pH}$-meter.

\section{Reagents}

Analytical grade reagents were used in this study. $\mathrm{Bi}\left(\mathrm{NO}_{3}\right)_{3} \cdot 5 \mathrm{H}_{2} \mathrm{O}$ (Riedel-de Haen) and $\mathrm{Pb}\left(\mathrm{NO}_{3}\right)_{2}$ (Wagtech International Ltd. UK), were used for preparation of electrode modifier and analyte, respectively. $\mathrm{CH}_{3} \mathrm{COONa}$ (BDH Chemicals Ltd, Poole, England) and $\mathrm{CH}_{3} \mathrm{COOH}$ (Merck KGaA 64271 Darmstadt, Germany) were used to prepare supporting electrolyte. Deionized water was used to prepare all standard and sample solutions throughout the experiment. Lignin was extracted from Hagenia abyssinica using the procedure reported in the literature [44, 45]. Briefly: about $1 \mathrm{~kg}$ of ground wood sample was dried at $60{ }^{\circ} \mathrm{C}$ for $24 \mathrm{~h}$ and the wax was extracted with toluene and dry ethanol $(2: 1 \mathrm{v} / \mathrm{v})$ for $6 \mathrm{~h}$. The sample free of wax was treated with $7.5 \%(\mathrm{w} / \mathrm{v}) \mathrm{NaOH}$ at $90-100{ }^{\circ} \mathrm{C}$ for $6 \mathrm{~h}$ and filtered. The filtrate was acidified by adding $5 \mathrm{M} \mathrm{H}_{2} \mathrm{SO}_{4}(\mathrm{pH}=5.5)$ and three times of ethanol by volume and then washed with $70 \%$ ethanol to precipitate the hemicelluloses. Ethanol was then evaporated from the filtrate and washed with $1 \%(\mathrm{v} / \mathrm{v}) \mathrm{H}_{2} \mathrm{SO}_{4}$ and dried at $120{ }^{\circ} \mathrm{C}$ to obtain the pure lignin.

\section{Solution preparation}

Stock solutions of bismuth(III) and lead(II) (1 mM each) were prepared using $\mathrm{Bi}\left(\mathrm{NO}_{3}\right)_{3} \cdot 5 \mathrm{H}_{2} \mathrm{O}$ and $\mathrm{Pb}\left(\mathrm{NO}_{3}\right)_{2}$, respectively, in $0.1 \mathrm{M}$ acetate buffer, which was prepared from $\mathrm{CH}_{3} \mathrm{COONa}$ and $\mathrm{CH}_{3} \mathrm{COOH}$ using deionized water. Different desire concentrations of $\mathrm{Bi}(\mathrm{III})$ and $\mathrm{Pb}(\mathrm{II})$ were 
prepared by diluting from the stock solution. Lignin solutions for adsorption were prepared using the target metal solution as required.

Preparation of bismuth film electrode (BiFE) and square wave anodic stripping voltammetry (SWASV) measurements

Glassy carbon electrode was first assiduously polished on a polishing pad using $0.05 \mu \mathrm{m}$ alumina powder and thoroughly rinsed with distilled water. Then, BiFE were prepared by in situ potentiostatic method using a three electrode system on a glassy-carbon as a working electrode, the $\mathrm{Ag} / \mathrm{AgCl} / \mathrm{Cl}$ (satd) as reference electrode and platinum wire as a counter electrode from the $0.1 \mathrm{M}$ acetate buffer solution ( $\mathrm{pH} 4.6$ ) containing $1 \mathrm{mg} \mathrm{L}^{-1}$ of bismuth(III) together with target heavy metal ion at a deposition potential of $-1.2 \mathrm{~V}$ for $240 \mathrm{~s}$. After the deposition step, the SWASVs were recorded by scanning the potential from -1.2 to $0.1 \mathrm{~V}$ with the frequency of 15 $\mathrm{Hz}$, potential step of $4 \mathrm{mV}$, and amplitude of $25 \mathrm{mV}$. Prior to each measurement, the cleaning step was applied by holding the potential of working electrode at $-0.3 \mathrm{~V}$ for $30 \mathrm{~s}$. The experiments were carried out at room temperature in non-deaerated solutions.

\section{Batch adsorption experiment}

$20 \mathrm{mg}$ of powdered lignin were accurately weighed and treated with $10 \mathrm{~mL}$ solutions of $100 \mathrm{mg}$ $\mathrm{L}^{-1} \mathrm{~Pb}(\mathrm{II})$ ion in $0.1 \mathrm{M}$ acetate buffer using $100 \mathrm{~mL}$ Erlenmeyer flasks. The flasks were completely sealed and agitated in a shaker at room temperature for $80 \mathrm{~min}$ in all experiments while the mixture was shaken 5 to $160 \mathrm{~min}$ for contact time study. The equilibrium concentration $\left(\mathrm{C}_{\mathrm{e}}, \mathrm{mg} \mathrm{L}^{-1}\right)$ of $\mathrm{Pb}(\mathrm{II})$ ion in the residual aqueous phase was measured using SWASV and determined from the calibration curve. Removal efficiency $\left(R_{E}\right)$ and equilibrium adsorption capacity $\left(\mathrm{q}_{\mathrm{e}}, \mathrm{mg} \mathrm{g}^{-1}\right)$ of the batch experiments were calculated using Eq. (1) and (2) [7].

$R_{E}(\%)=\frac{C_{o}-C_{e}}{C_{o}} X 100$

$q_{e}=\frac{V\left(C_{o}-C_{e}\right)}{m}$

where $\mathrm{V}$ is the volume of the solution, $\mathrm{m}$ is the mass of lignin, $\mathrm{C}_{\mathrm{o}}$ and $\mathrm{C}_{\mathrm{e}}$ are the initial and equilibrium concentrations of lead ion, respectively.

\section{RESULTS AND DISCUSSION}

\section{FTIR and elemental analysis}

Fourier transform infrared (FTIR) was used to determine the main functional groups present on the adsorbent lignin extracted from Hagenia abysinica. The strong broad peak at $3426 \mathrm{~cm}^{-1}$ was due to the stretching vibrations of aromatic and aliphatic $\mathrm{OH}$ groups and the characteristic shoulder peak at $2849 \mathrm{~cm}^{-1}$ is $\mathrm{C}-\mathrm{H}$ stretch of $\mathrm{O}-\mathrm{CH}_{3}$ of coniferyl/sinapyl alcohols as shown in Figure 1. The strong peaks at about 1500 and $1609 \mathrm{~cm}^{-1}$ were related to aromatic ring vibrations of the phenyl propane skeleton in coniferyl alcohol. All these IR signals indicate that the alkali lignin is congruent with other lignin reported in the literature [46]. In addition, elemental analysis was performed and the lignin was found to contain C $(46.3 \%), \mathrm{H}(5.04 \%), \mathrm{S}(2.25 \%)$ and $\mathrm{O}(46.4 \%)$. 


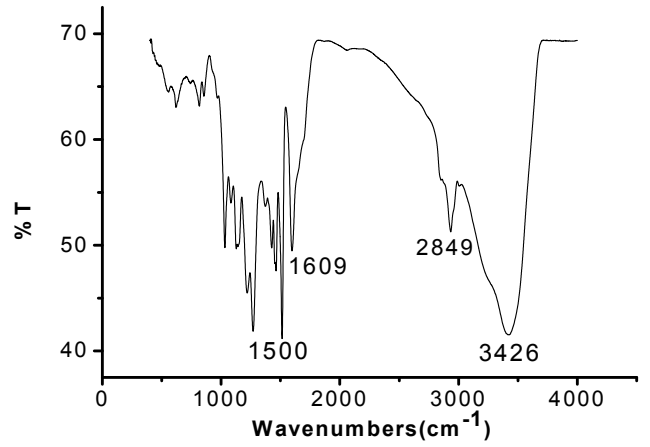

Figure 1. FTIR spectrum of lignin.

\section{Effect of deposition time}

The effect of deposition time on the anodic stripping signals of lead was studied in the range of $30-390 \mathrm{~s}$ in solutions containing $60 \mu \mathrm{g} \mathrm{L}{ }^{-1} \mathrm{~Pb}$ (II) ions and the results are depicted in Figure 2. The peak current of the voltammetric stripping signals was found to increase significantly with increasing the deposition time due to an increase in the amount of $\mathrm{Pb}$ (II) deposited at the electrode surface. Since the peak current of $\mathrm{Pb}(\mathrm{II})$ ions is continually increasing with deposition time, a deposition time of $240 \mathrm{~s}$ was used for further analysis as a compromise between relatively short analysis time and high sensitivity.

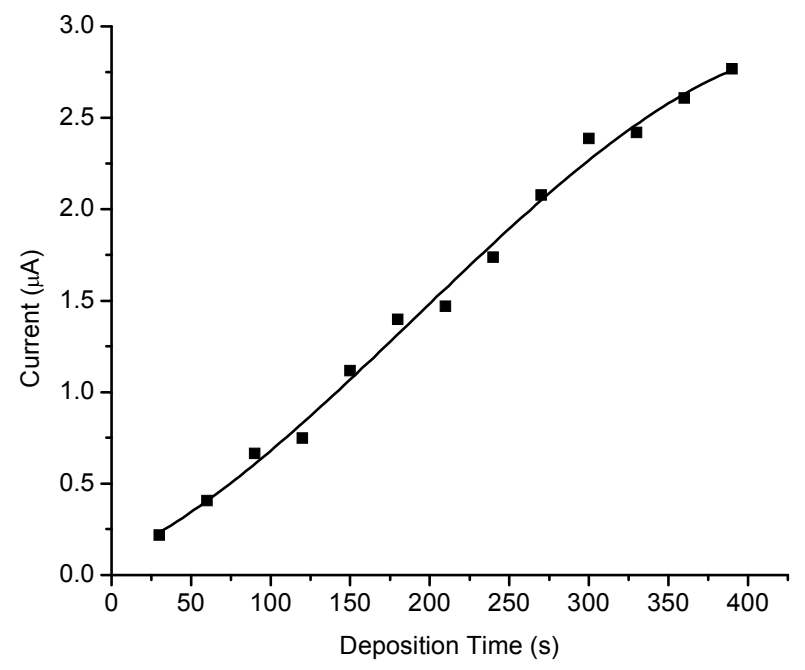

Figure 2. Effect of deposition time on the square wave anodic stripping voltammetric response of $60 \mu \mathrm{g} \mathrm{L}^{-1} \mathrm{~Pb}(\mathrm{II})$ at $\mathrm{BiFE}$. Experimental conditions: $1 \mathrm{mg} \mathrm{L}^{-1} \mathrm{Bi}(\mathrm{III})$ in acetate buffer with $\mathrm{pH}$ 4.6.

\section{Effect of deposition potential}

The effect of the deposition potential on the $\mathrm{Pb}(\mathrm{II})$ stripping signals was investigated by varying the potential between -0.6 and $-1.4 \mathrm{~V}$. The signals of $\mathrm{Pb}(\mathrm{II})$ increased with increasing potential

Bull. Chem. Soc. Ethiop. 2016, 30(3) 
and reached a maximum at $-1.2 \mathrm{~V}$ as depicted in Figure 3 . When the potential was more negative than $-1.2 \mathrm{~V}$, the signals decreased slightly probably due to hydrogen evolution. Hence, $-1.2 \mathrm{~V}$ was chosen as the optimum deposition potential for the determination of $\mathrm{Pb}(\mathrm{II})$.

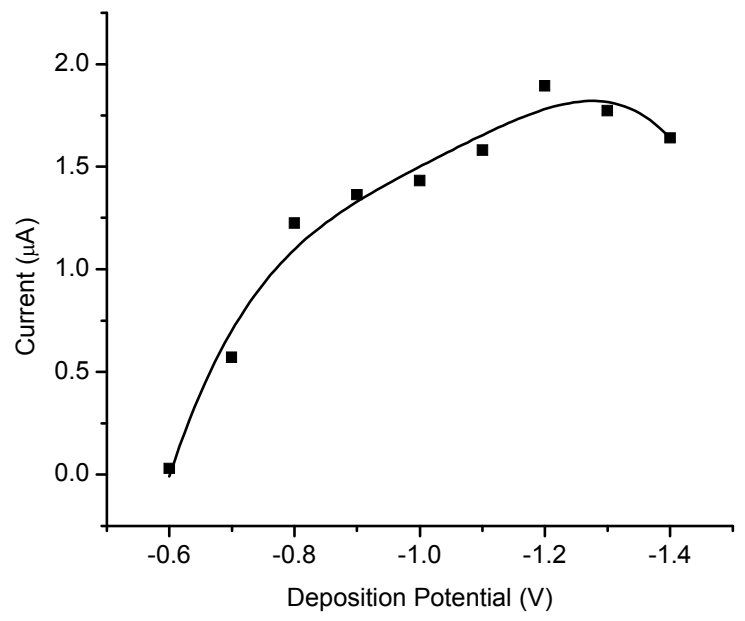

Figure 3. Effect of deposition potential on the square wave anodic stripping voltammetric response for $60 \mu \mathrm{g} \mathrm{L}^{-1} \mathrm{~Pb}(\mathrm{II})$ at BiFE. Experimental conditions: $1 \mathrm{mg} \mathrm{L}^{-1} \mathrm{Bi}(\mathrm{III})$ deposition time $240 \mathrm{~s}, \mathrm{pH} 4.6$.

\section{Calibration curve}

After optimizing the electrochemical parameters like the deposition time and deposition potential a calibration curve was constructed to determine the concentration of $\mathrm{Pb}$ (II) for subsequent analysis. Using the optimized experimental conditions, anodic stripping voltammetric measurements were carried out for different concentration of $\mathrm{Pb}$ (II) (10-200 $\mu \mathrm{g}$ $\mathrm{L}^{-1}$ ) and the results are shown in Figure 4. The calibration curve obtained using a deposition potential of $-1.2 \mathrm{~V}$ and a deposition time of $240 \mathrm{~s}$ was linear in the range examined (10-200 $\mu \mathrm{g}$ $\mathrm{L}^{-1}, \mathrm{R}^{2}=0.9995, \mathrm{n}=11$ ) with sensitivity of $0.04389 \pm 0.00032 \mu \mathrm{AL} \mu \mathrm{g}^{-1}$. The limit of detection (LOD) was calculated using Eq. (3):

$L O D=\frac{3 S D}{m}$

where SD is the standard deviation of blank solution and $\mathrm{m}$ is the slope of the calibration line. The standard deviation (SD) was calculated by measuring the anodic stripping signals of 20 samples of the blank solution. The detection limit calculated was found to be $0.24 \mu \mathrm{g} \mathrm{L}^{-1}$ with RSD of $1.1 \%$.

\section{Effect of $\mathrm{pH}$ and contact time}

The effect of $\mathrm{pH}$ on the adsorption of $60 \mu \mathrm{g} \mathrm{L}^{-1}$ of lead ion on $2 \mathrm{mg} \mathrm{mL}^{-1}$ dose of adsorbent was carried out by varying $\mathrm{pH}$ in the range from 3.6 to 5.6. It was observed that the removal efficiency reached maximum at $\mathrm{pH} 4.6$ as depicted in Figure 5. The poor removal efficiency at lower $\mathrm{pH}$ is attributed to the competitive nature of proton with lead ion while lower solubility of $\mathrm{Pb}$ (II) salt suppresses the percent removal at higher $\mathrm{pH}$ than 4.6 [47]. Therefore, $\mathrm{pH} 4.6$ was taken as an optimum $\mathrm{pH}$ for the adsorption of lead ion for subsequent experiments. 


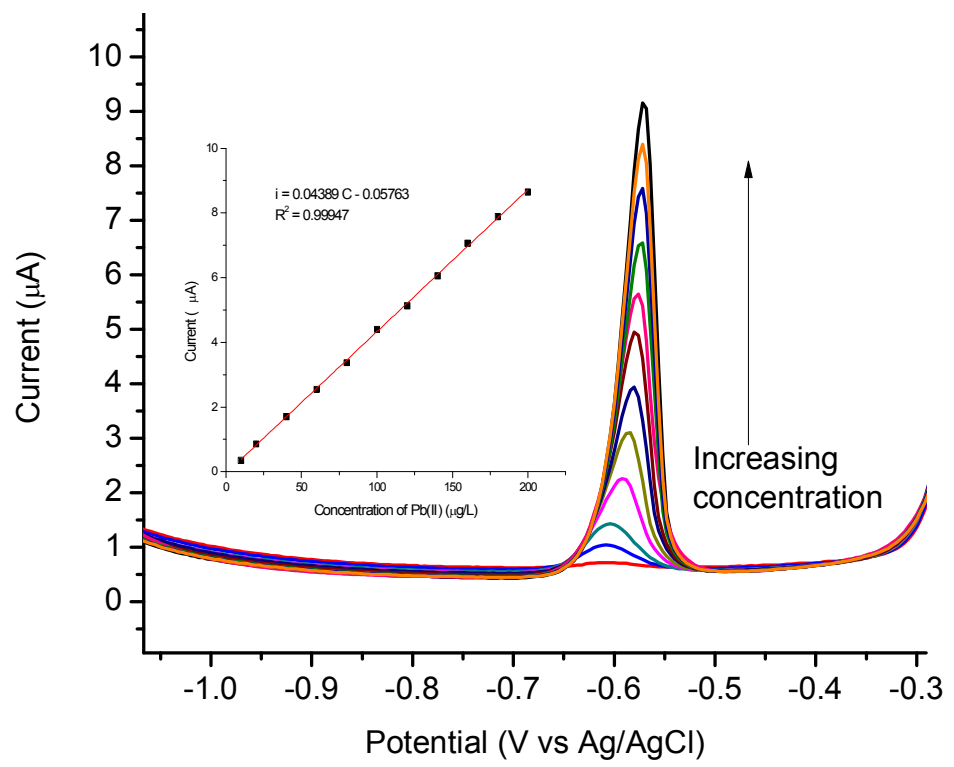

Figure 4. Square wave anodic stripping voltammograms for the linear range of calibration curve for standard addition of 10 to $200 \mu \mathrm{g} \mathrm{L}^{-1} \mathrm{~Pb}$ (II) from bottom to top on glassy carbon electrode in $0.1 \mathrm{M}$ acetate buffer with $\mathrm{pH}=4.6$ in the presence of $1 \mathrm{mg} \mathrm{L}^{-1} \mathrm{Bi}(\mathrm{III})$. The inset is calibration curve peak current against the $\mathrm{Pb}(\mathrm{II})$ concentration from 10 to $200 \mu \mathrm{g} \mathrm{L}^{-1}\left(\mathrm{R}^{2}=0.9995\right)$.

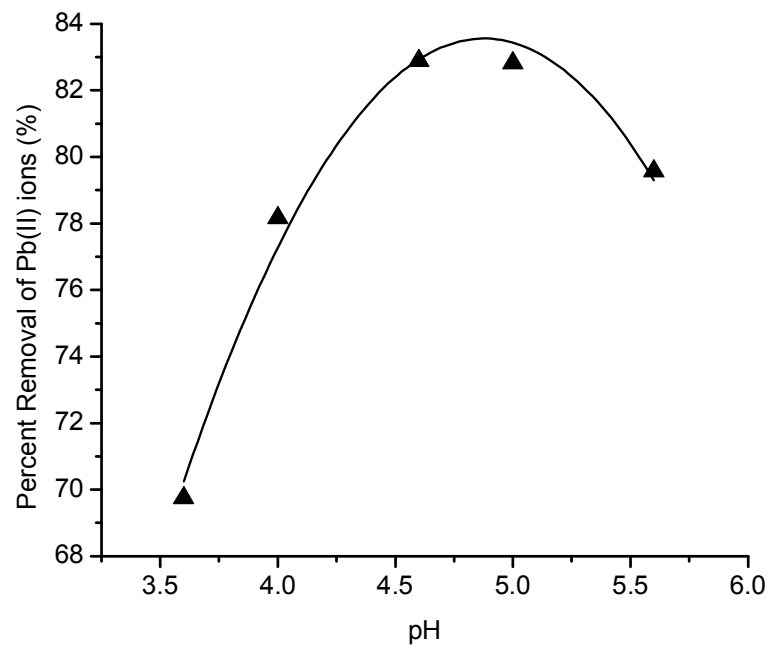

Figure 5. Effect of $\mathrm{pH}$ on the removal of $\mathrm{Pb}$ (II) with an initial concentration of $60 \mu \mathrm{g} \mathrm{L}^{-1}$ in acetate buffer with $2 \mathrm{mg} \mathrm{mL}^{-1}$ adsorbent dose for adsorption time of $80 \mathrm{~min}$.

The removal efficiency of lignin adsorbent was also investigated by varying the contact time with lead metal ion. A rapid adsorption of $\mathrm{Pb}$ (II) ion was observed in the first $40 \mathrm{~min}$, then the 
adsorption rate decreased gradually and finally got level off presumably due to the saturation of adsorbent sites (Figure 6).

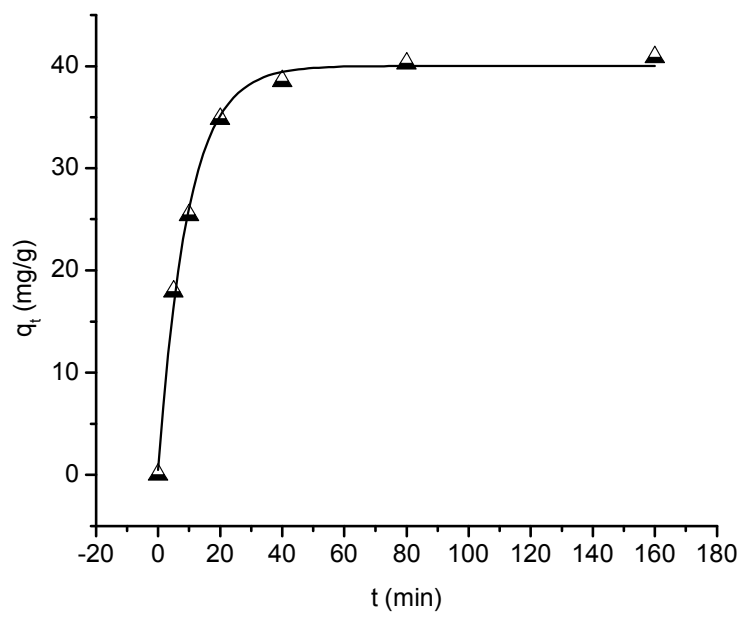

Figure 6. Adsorption capacity - time profile for lead ion in contact with lignin: $60 \mu \mathrm{g} \mathrm{L}^{-1} \mathrm{~Pb}(\mathrm{II})$ ion concentration in $0.1 \mathrm{M}$ acetate buffer $(\mathrm{pH}=4.6)$ with adsorbent dose of $2 \mathrm{mg} \mathrm{mL}^{-1}$ and contact time of $0,5,10,20,40,80$ and $160 \mathrm{~min}$.

In addition, the effect of lignin dosage on $\mathrm{Pb}(\mathrm{II})$ ion adsorption was studied in the range of $0.5-5 \mathrm{mg} \mathrm{mL}^{-1}$. The percentage of lead ion removal increases with lignin dosage from $0.5-5 \mathrm{mg}$ $\mathrm{mL}^{-1}$, starting from $40.2 \%$ to $88.2 \%$ as depicted in Figure 7 . The rate of lead adsorption on lignin does not significantly increase larger than $5 \mathrm{mg} \mathrm{mL}^{-1}$ lignin dosage. This can be attributed to the overlapping of active sites of the adsorbent at higher dosage which results in reduced effective surface area [48].

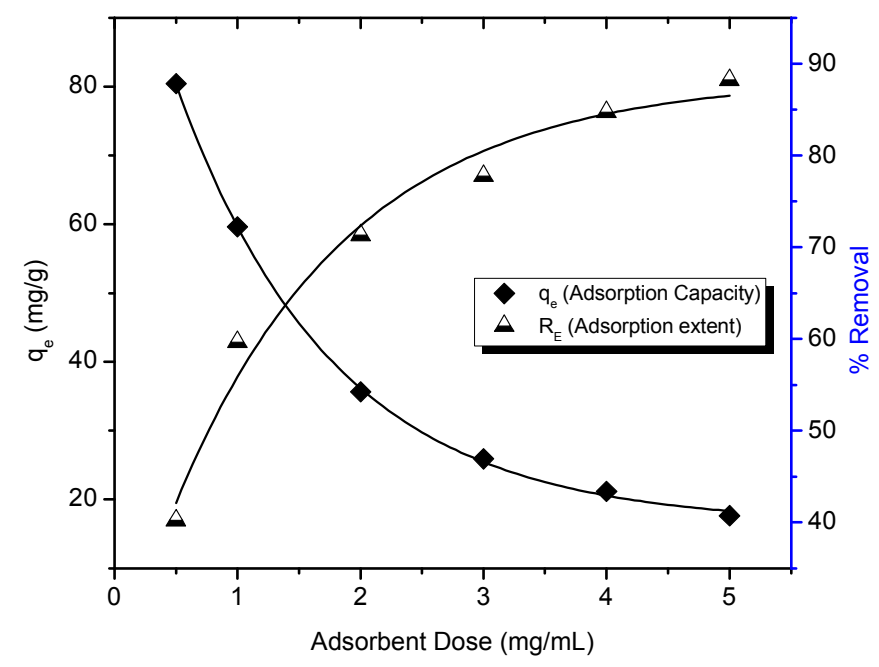

Figure 7. The effect of adsorbent dose on the removal of $\mathrm{Pb}(\mathrm{II})$ ion and its adsorption capacity: $\mathrm{pH}=4.6$, initial metal concentration of $100 \mathrm{mg} \mathrm{L}^{-1}$ and adsorption time of $80 \mathrm{~min}$.

Bull. Chem. Soc. Ethiop. 2016, 30(3) 
Adsorption isotherm models

The adsorption isotherms indicate the distribution of adsorbed molecules between the solid and liquid phases when the adsorption reaches equilibrium. One of the adsorption isotherms is the Langmuir isotherm which assumes monolayer adsorption onto a surface containing a finite number of adsorption sites of uniform strategies [49]. Once the adsorbent sites are filled, no further adsorption can take place at the sites. The isotherm is represented by Eq. (4).

$\frac{1}{q_{e}}=\frac{1}{K_{L} q_{\max } C_{e}}+\frac{1}{q_{\max }}$

The constants $\mathrm{K}_{\mathrm{L}}$ and $\mathrm{q}_{\max }$ are related to the energy of adsorption and maximum adsorption capacity, respectively and their values were obtained from the slope and intercept of the plot of $1 / \mathrm{q}_{\mathrm{e}}$ against $1 / \mathrm{C}_{\mathrm{e}}$ and are summarized in Table 1 . The linearityof this plot is not good as indicated in Figure 8. The adsorption capacity obtained from the Langmuir isotherm also significantly deviates from the experimental result.

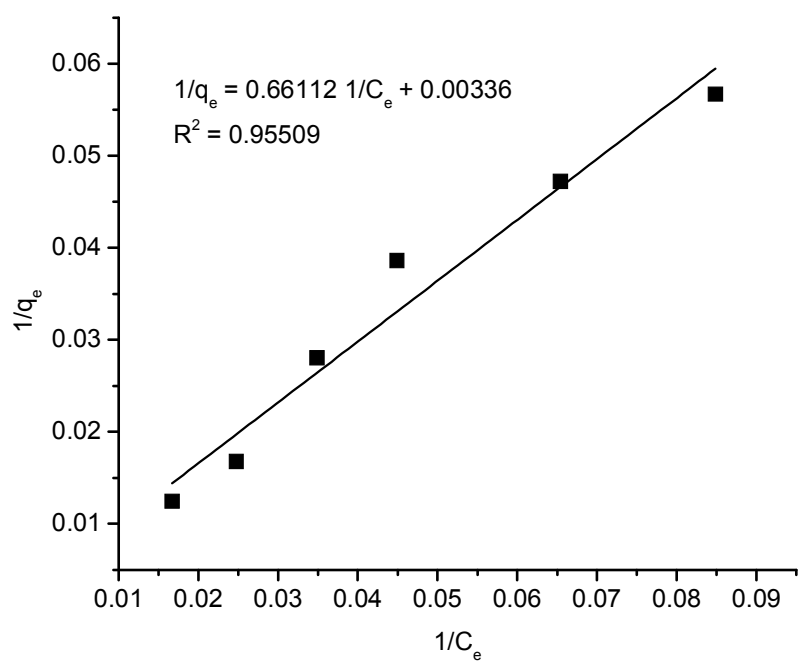

Figure 8. Langmuir fitting of adsorption of lead on to lignin.

The Freundlich isotherm has been derived by assuming an expression encompassing the surface heterogeneity and the exponential distribution of active sites and their energies. The Freundlich isotherm shows that the heavy metal ions adsorption occurs on a heterogeneous surface by multilayer sorption [50, 51]. The Freundlich isotherm is represented byEq. (5) and Eq. (6) for nonlinear and linear, respectively.

$q_{e}=K_{F} C_{e}^{1 / n}$

The equation can be linearized and temperature dependent constants $\mathrm{K}_{\mathrm{F}}$ and $1 / \mathrm{n}$ are obtained by linear regression:

$\ln q_{e}=\ln K_{F}+\frac{1}{n} \ln C_{e}$

where $\mathrm{K}_{\mathrm{F}}$ and $\mathrm{n}$ are Freundlich constants which correspond to adsorption capacity and adsorptionintensity, respectively. The plot of $\operatorname{lnq}_{\mathrm{e}}$ versus $\ln C_{\mathrm{e}}$ is used to determine $\mathrm{K}_{\mathrm{F}}$ and $\mathrm{n}$ 
values. The $\mathrm{n}$ value indicates the degree of nonlinearity between solution concentration and adsorption as follows: if $\mathrm{n}=1$, then adsorption is linear; if $\mathrm{n}<1$, then adsorption is a chemical process; if $\mathrm{n}>1$, then adsorption is a physical process. The $\mathrm{n}$ value in Freundlich equation was found to be 1.03 (Table 1). Here, since $n$ value lies between 1 and 10, adsorption of lead ion onto lignin is likely a physical adsorption process. The maximum adsorption capacity $\left(\mathrm{q}_{\max }\right)$ from theFreundlich isotherm was calculated usingEq. (7) [52]:

$K_{F}=\frac{q_{\max }}{c_{0}^{1 / n}}$

where $\mathrm{C}_{0}$ is the initial concentration of the solute in the bulk solution $\left(\mathrm{mg} \mathrm{L}^{-1}\right)$ and $\mathrm{q}_{\max }$ is the Freundlich maximum adsorption capacity $\left(\mathrm{mg} \mathrm{g}^{-1}\right)$.

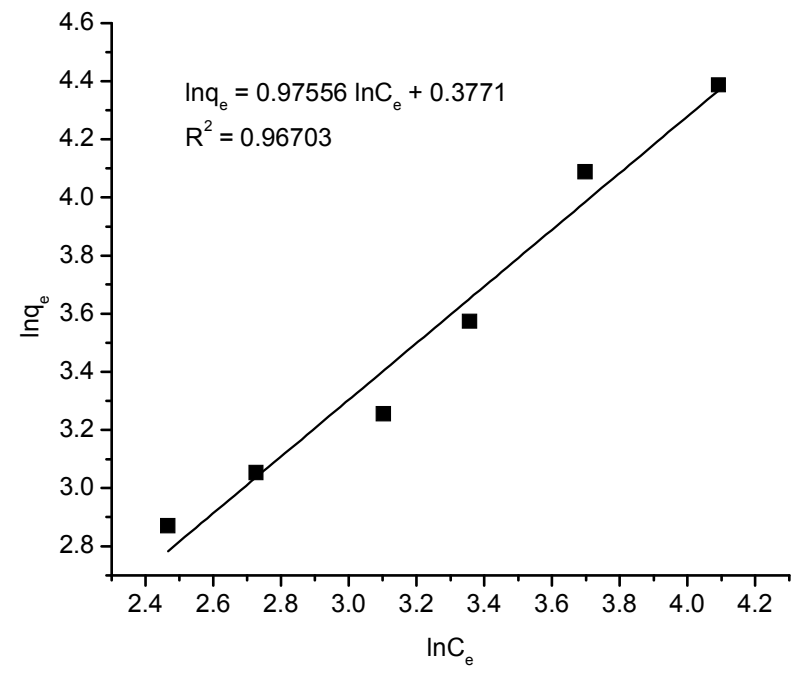

Figure 9. Freundlichfitting of adsorption of lead on to lignin.

Table 1. The Langmuir and Freundlich isotherm for the adsorption of lead ion onto lignin at $298 \mathrm{~K}$.

\begin{tabular}{|l|c|c|c|c|c|c|c|}
\hline Exp't & \multicolumn{3}{|c|}{ Langumir } & & \multicolumn{3}{c|}{ Freundlich } \\
\hline $\mathrm{q}_{\mathrm{e}}(\mathrm{mg} / \mathrm{g})$ & $\mathrm{K}_{\mathrm{L}}(\mathrm{L} / \mathrm{mg})$ & $\mathrm{q}_{\max }(\mathrm{mg} / \mathrm{g})$ & $\mathrm{R}^{2}$ & $\mathrm{q}_{\max }(\mathrm{mg} / \mathrm{g})$ & $\mathrm{n}$ & $\mathrm{K}_{\mathrm{F}}\left((\mathrm{mg} / \mathrm{g})(\mathrm{L} / \mathrm{mg})^{1 / \mathrm{n}}\right)$ & $\mathrm{R}^{2}$ \\
\hline 80.41 & 0.005 & 297.6 & 0.955 & 127 & 1.03 & 1.46 & 0.967 \\
\hline
\end{tabular}

To obtain the most appropriate model for the lead ion adsorption, data were fitted to Langmuir and Freundlich isotherms. It was observed that the Freundlich adsorption isotherm was found to be a better model to describe the adsorption of lead ion onto lignin with a correlation coefficient $\mathrm{R}^{2}$ of 0.967 as indicated in Figure 9.

\section{Adsorption kinetics}

The pseudo-first-order and pseudo second-order models were used to test adsorption kinetics of $\mathrm{Pb}$ (II) ion. The rate expression of Lagergren of pseudo-first-order is given by Eq. (8) [53].

$\log \left(q_{e}-q_{t}\right)=\log q_{e}-\frac{k_{1}}{2.303} t$

Where $\mathrm{q}_{\mathrm{t}}(\mathrm{mg} / \mathrm{g})$ is the amount of adsorbed lead ion onto the lignin at time $\mathrm{t}, \mathrm{k}_{1}$ is the rate constant of first order adsorption and $\mathrm{q}_{\mathrm{e}}$ is the equilibrium adsorption capacity. The plot of $\log \left(\mathrm{q}_{\mathrm{e}}\right.$

Bull. Chem. Soc. Ethiop. 2016, 30(3) 
- $\mathrm{q}_{\mathrm{t}}$ ) versus $\mathrm{t}$ shows poor linearity (Figure 10A) and the values of $\mathrm{q}_{\mathrm{e}}$ and $\mathrm{k}_{1}$ was obtainedfrom their intercept and slope, respectively (Table 2).
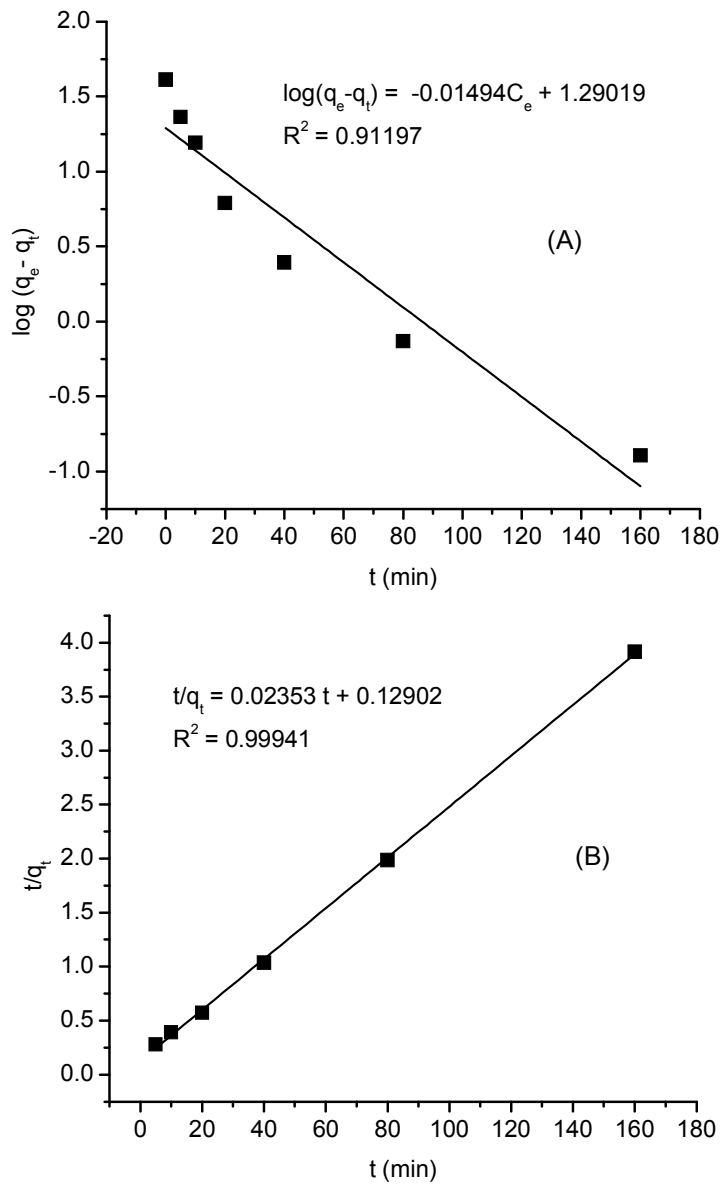

Figure 10. Kinetics models for $\mathrm{Pb}(\mathrm{II})$ ion adsorbed onto lignin : A) Pseudo first-order B) Pseudo second-order.

Table 2. Comparison between adsorption rate constants for the kinetics models.

\begin{tabular}{|c|c|c|c|c|c|c|c|}
\hline \multirow{2}{*}{$\begin{array}{c}\text { Initial } \\
\text { conc. } \\
\text { (mg/L) }\end{array}$} & \multirow[b]{2}{*}{$\begin{array}{l}\mathrm{q}_{\mathrm{e}} \text { exp. } \\
(\mathrm{mg} / \mathrm{g})\end{array}$} & \multicolumn{3}{|c|}{ Pseudo-first-order model } & \multicolumn{3}{|c|}{ Pseudo-second-order model } \\
\hline & & $\begin{array}{c}\mathrm{k}_{1} \\
\left(\mathrm{x} 10^{-3} \min ^{-1}\right)\end{array}$ & $\begin{array}{l}\mathrm{q}_{\mathrm{e}} \mathrm{cal} . \\
(\mathrm{mg} / \mathrm{g})\end{array}$ & $\mathrm{R}^{2}$ & $\begin{array}{c}\mathrm{k}_{2} \\
\left(\mathrm{x} 10^{-3} \mathrm{gmg}^{-1} \mathrm{~min}^{-1}\right)\end{array}$ & $\begin{array}{l}\mathrm{q}_{\mathrm{e}} \text { cal. } \\
(\mathrm{mg} / \mathrm{g})\end{array}$ & $\mathrm{R}^{2}$ \\
\hline 100 & 41 & 34.4 & 19.5 & 0.912 & 4.29 & 42.5 & 0.999 \\
\hline
\end{tabular}

The pseudo second-order kinetic model in its linearized expression is also given by Eq. (9) [54]:

$\frac{t}{q_{t}}=\frac{1}{k_{2} q_{e}^{2}}+\frac{1}{q_{e}} t$

where $\mathrm{k}_{2}(\mathrm{~g} / \mathrm{mg} \mathrm{min})$ is the rate constant of second-order adsorption. The plot $\mathrm{t} / \mathrm{q}$ versus $\mathrm{t}$ exhibits linearity with a very good correlation coefficient $R^{2}$ of 0.9994 (Figure 10B), indicating that lead ion adsorption onto lignin obeys second-order kinetics. The values $\mathrm{q}_{\mathrm{e}}$ and $\mathrm{k}_{2}$ were obtained from the slope and intercept of the plot and presented in Table 2.

Bull. Chem. Soc. Ethiop. 2016, 30(3) 
Table 3. Adsorption equilibrium time and adsorption capacities of some materials reported in the literature.

\begin{tabular}{|l|c|c|c|}
\hline Adsorbent & $\begin{array}{c}\text { Equilibrium } \\
\text { time (min) }\end{array}$ & $\begin{array}{c}\text { Adsorption capacity } \\
\left(\mathrm{mgg}^{-1}\right) \text { of } \mathrm{Pb}(\mathrm{II})\end{array}$ & Reference \\
\hline Polar wood lignin & 120 & 8.9 & 55 \\
\hline Kraft lignin & - & 14.9 & 56 \\
\hline Alkaline lignin & 30 & 69.8 & 7 \\
\hline Modified soda lignin & 60 & 46.0 & 57 \\
\hline Amine modified lignin & 60 & 61.0 & 58 \\
\hline Bi-functionalized lignin & - & 53.9 & 59 \\
\hline Lignin from Hagenia abysinica & 80 & 80.4 & Present study \\
\hline
\end{tabular}

\section{CONCLUSION}

Results from this study showed that the maximum adsorption capacity of $\mathrm{Pb}$ (II) ion onto the dry weight lignin was found to be $80.41 \mathrm{mg} \mathrm{g}^{-1}$. This value is compared with other similar adsorbents (Table 3 ) and the alkali lignin extracted from indigenous plant Hagenia abyssinica is an effective adsorbent for lead ion removal. The adsorption equilibrium data fitted well to the Freundlich isotherm model with a better correlation coefficient of 0.967 compared to that of Langmuir model $(0.955)$. The $\mathrm{n}$ value in the present investigation was greater than one, indicating that the adsorption of lead ion onto lignin is favorable. Besides, the adsorption kinetics follows pseudo-second order. This locally available lignin material has the potential to be used as an efficient and cost effective adsorbent for the removal of lead ion from waste water.

\section{ACKNOWLEDGEMENTS}

The authors acknowledge the International Science Program (ISP) Uppsala University, Sweden, for financial support and S. Dagne for the laboratory assistance in the extraction and purification of lignin.

\section{REFERENCES}

1. Nguyen, T.C.; Loganathan, P.; Nguyen, T.V.; Vigneswaran, S.; Kandasamy, J.; Naidu, R. Chem. Eng. J. 2015, 270, 393.

2. El-Toony, M.M.; Abdel-Geleel, M.; Aly, R.O.; Ali, H.F. Nat. Sci. 2011, 9, 82.

3. Begum, S.A.S.; Tharakeswar, Y.; Kalyan, Y.; Naidu, G.R. J. Encapsul. Adsor. Sci. 2015, 5, 93.

4. Apak, R.; Guclu, K.; Turgut, M.H. J. Colloid Interf. Sci. 1998, 203, 122.

5. Celik, A.; Demirbas, A. Energy Sour. 2005, 27, 1167.

6. Senthilkumaar, S; Bharathi, S.; Nithyanandhi, D.; Subburam, V. Bioresor. Technol. 2000, $75,163$.

7. Ge, Y.; Xiao, D.; Li, Z.; Cui, X. J. Mater. Chem. A 2014, 2, 2136.

8. Yao, Q.; Xie, J.; Liu, J.; Kang, H.; Liu, Y. J. Polym. Res. 2014, 21, 465.

9. Çay, S.; Uyanik, A.; Özasik, A. Sep. Purif. Technol. 2004, 38, 273.

10. Momcilovic, M.; Purenovic, M.; Bojic, A.; Zarubica, A.; Randelovic, M. Desalination 2011, 276, 53.

11. Hikmat, N.A.; Qassim, B.B.; Khethi, M.T. Am. J. Chem. 2014, 4, 116.

12. Argun, M.E.; Dursun, S.; Ozdemir, C.; Karatas, M. J. Hazard. Mater. 2007, 141, 77.

13. Ngah, W.S.W.; Hanafiah, M.A.K.M. Bioresor. Technol. 2008, 99, 3935.

14. Babel, S.; Kurniawan, T.A. Chemosphere 2004, 54, 951.

15. Esalah, J.O.; Weber, M.E.; Vera, J.H. Canad. J. Chem. Eng. 2000, 78, 954.

16. Fong, M.P.; Pradeep, K.; Tjoon, T.T.; Omar, A.K. M.; Kailas, L.W. J. Taiwan Inst. Chem. Eng. 2011, 42, 809.

17. Eswed, B.; Alshaaer, M.; Yousef, R.I.; Hamadneh, I.; Khalili, F. Adv. Mater. Phys. Chem. 2012, 2, 119.

18. Dabrowski, A.; Hubicki, Z.; Podkoscielny, P.; Robens, E. Chemosphere 2004, 56, 91. 
19. Wahaab, R.A.; Moawad, A.K.; Taleb, E.A.; Ibrahim, H.S.; Nazer, H.A.H. World Appl. Sci. J. 2010, 8, 462.

20. Juang, R.S.; Shiau, R.C. J. Membr. Sci. 2000, 165, 159.

21. Nourbakhsh, M.N.; Kiliçarslan, S.; Ilhan, S.; Ozdag, H. Chem. Eng. J. 2002, 85, 351.

22. Singh, D.; Tiwari, A.; Gupta, R. J. Agric. Technol. 2012, 8, 1.

23. Wang, Z.; Feng, Y.; Hao, X.; Huang, W.; Feng, X. J. Mater. Chem. A 2014, 2, 10263.

24. Ogawa, S.; Katoh, M.; Sato, T. Environ. Technol. 2015, 36, 2647.

25. Rao, L.N. Int. J. Eng. Res. Sci. Tech. 2013, 2, 65.

26. Beyki, M.H.; Shemirani, F. RSC Adv. 2015, 5, 22224.

27. Zargoosh, K.; Abedini, H.; Abdolmaleki, A.; Molavian, M.R. Ind. Eng. Chem. Res. 2013, $52,14944$.

28. Liu, F.; Yu, J.; Ji, X.; Qian, M. ACS Appl. Mater. Interf. 2015, 7, 1824.

29. Cozmuta, L.M.; Cozmuta, A.M.; Peter, A.; Nicula, C.; Tutu, H.; Indrea, E. J. Environ. Manag. 2014, 137, 69.

30. Ahmaruzzaman, M. Adv. Colloid Interf. Sci. 2011, 166, 36.

31. Demirbas, A. J. Hazard. Mater. 2008, 157, 220.

32. Vieira, M.G.A.; de Almeida Neto, A.F.; da Silva, M.G.C.; Carneiro, C.N.; MeloFilho, A.A. Braz. J. Chem. Eng. 2014, 31, 519.

33. Dixit, A.; Dixit, S.; Goswami, C.S. J. Mater. Environ. Sci. 2014, 5, 540.

34. Salman, M.; Farooq, U.; Athar, M. Rev. Environ. Sci. Biotech. 2015, 14, 211.

35. Peng, X.; Zhong, L.; Ren, J.; Sun, R. J. Agric. Food Chem. 2012, 60, 3909.

36. Hurdebise, Q.; Tarayre, C.; Fischer, C.; Colinet, G.; Hiligsmann, S.; Delvigne, F. Sensors 2015, 15, 8981.

37. Nikolic, R.; Krstic, N.; Jovanovic, J.; Kocic, G.; Cvetkovic, T.P.; Stevanovic, N.R. Toxicol. Ind. Health 2015, 31, 239.

38. Inyang, M.; Gao, B.; Zimmerman, A.R.; Ding, W.; Cao, X. Sep. Sci. Technol. 2011, 46, 1950.

39. Agarwal, A.; Kapil, B. Int. J. Sci. Res. 2014, 3, 2047.

40. Teju, E.; Megersa, N.; Chandravanshi, B.S.; Zewge, F. Bull. Chem. Soc. Ethiop. 2014, 28, 161.

41. Zakzeski, J.; Bruijnincx, P.C.A.; Jongerius, A.L.; Weckhuysen, B.M. Chem. Rev. 2010, 110, 3552.

42. Yang, S.; Wen, J.; Yuan, T.; Sun, R. RSC Adv. 2014, 4, 57996.

43. Song, Z.; Li, W.; Liu, W.; Yang, Y.; Wang, N.; Wang, H.; Gao, H. RSC Adv. 2015, 5, 13028.

44. Admassie, S.; Nilsson, T.Y.; Inganäs, O. Phys. Chem. Chem. Phys. 2014, 16, 24681.

45. Altwaiq, A.; Khouri, S.J.; Alluaibi, S.; Lehmann, R.; Drucker, H.; Vogt, C. J. Mater. Environ. Sci. 2011, 2, 259.

46. Heitner, C.; Dimmel, D.R.; Schmidt, J.A. Lignin and Lignans, Advances in Chemistry, CRC Press: New York; 2010; p 122.

47. Lalhruaitluanga, H.; Jayaram, K.; Prasad, M.N.V.; Kumar, K.K. J. Hazard. Mater. 2010, $175,311$.

48. Asgari, G.; Roshani, B.; Ghanizadeh, G. J. Hazard. Mater. 2012, 217- 218, 123.

49. Khal, H.E.; Batis, N.H. New J. Chem. 2015, 39, 3597.

50. Zhu, S.; Yang, N.; Zhang, D. Mater. Chem. Phys. 2009, 113, 784.

51. Brdar, M.; Sciban, M.; Takaci, A.; Dosenovic, T. Chem. Eng. J. 2012, 183, 108.

52. Oualid, H.; Emmanuel, N. J. Hazard. Mater. 2007, 147, 381.

53. Ho, Y.S.; McKay, G. Water Res.1999, 33, 578.

54. McKay, G.; Ho, Y.S. Process Biochem.1999, 34, 451.

55. Demirbas, A. J. Hazard. Mater. B 2004, 109, 221.

56. Crist, R.H.; Martin, J.R.; Crist, D.R. Environ. Sci. Technol. 2002, 36, 1485.

57. Ibrahim, M.N.; Negash, W.S.W.; Norhiyana, M.S.; Daud, W.R.W.; Rafatullah, M.; Sulaiman, O.; Hashim, R.A. J. Hazard. Mater. 2010,182, 377.

58. Ge, Y.; Song, Q.; Li, Z. J. Ind. Eng. Chem. 2015, 23, 228.

59. Ge, Y.; Li, Z.; Kong, Y.; Song, Q.; Wang, K. J. Ind. Eng. Chem. 2014, 20, 4429. 